\title{
科学技術の世界における 要素還元と情報と総合
}

\section{尾 坂 芳 夫}

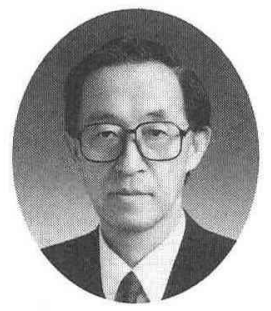

今日の科学は、“人の救済”を意識しながら、その認識水準から複合体と考えること ができない基本的構成要素としての素粒子にまで物質を還元し、また生体を核酸にま で還元するなどによって、自然の基本的理解を樑く推し進めている。技術は、そこに 統べる原理によって“自然に従い”ながら手を加之、また新しい機能を持つ人工物を 創出して多様な可能性を生み出している。このような科学と技術の発達の原動力をな しているものは、自然・社会の理解を限りなく深めることを願い、また文明を質的・ 量的に向上・拡大して利便を創出しようとする人間の欲求そのものである。

科学技術は、自然・社会のより根底にある原理を、より合理的に利用するようにな るほど、上部の要素がより強く関連し合う構造になり、またシステムが巨大化する。 この傾向は、荷電粒子の加速器や核融合炬などの装置、高速道路や都市などの社会基 盤施設などのように、人工物の今日的様態として顕著に現れており、またコンピュー 夕と高度情報通信技術の発達による金融・経済の世界化や、人間活動と環境・生態系 の問題などとして文明社会の諸及の相に浸透している。そして人工物が作る巨大シス テムには、高度の信頼性の保証という不可避な問題が発生している。安定したシステ ムを造るために採られるフールプルーフやフェイルセーフなどの諸々の対策は、小さ い“閉じた構造”を持つ機械・設備に対して一定の成果を挙げているが、“開いた構造” を持つ社会基盤施設には、個々の要素構造物としても全体の複合システムとしても、 自然と人間・社会を包む総合的視点からの検討を必要とする問題が残されている。

いうまでもなく、科学技術がどのように発達を続けるとしても、人類が究極的に求 めるものは、科学技術の発達それ自体ではない。全ての民族が固有文化の豊かさを享 受できる世界が求められているのである。今日まで合理主義を至上の原理として進ん できた繁栄の量的拡大の道は、“対峙する”視点で利用してきた有限の自然から反撃を 受けて、自然と共生しようとする方向に戦略を変更することを余儀なくされており、 またそこに根を持つ民族対立を惹き起こすという困難に突き当たろうとしている。こ れは壮大な歴史的実験であった。この結果は、科学技術の拠所を、人間が対峙する自 然の秩序にではなく、人間と自然の 総体を統べる秩序に求める方向が、 進むべき道であることを示唆してい る。人間と自然との持続的な共生は、 人類の繁栄秩序の構築のために不可 欠の条件であり、そして民族が固有

尾坂芳夫（おざかよしお 1930年生）

日本学術会議第 5 部会員、「学術と産業」特別委員会 委員、災害研究連絡委員会・構造工学研究連絡委員 会委員、東北学院大学教授、東北大学名誉教授、工 学博士

専門：土木工学、コンクリート構造 
文化の繁栄へ向けて活動できる現実的なゆとりのある世界秩序を構築していこうとす る意欲によってのみ、自然との持続的な共生を探ることが可能となるのであろう。そ こには、物質原理に拠る科学技術だけの問題ではなく、社会・経済ひいては文化の全 体に関わる問題が提起されている。このような共生の現実の在り方を考えるには、そ れを可能にする限りの平等と、資質に対応する寄与と実りの享受とについて、一定の 判断を前提としないわけにいかない。そして、その秩序へ至る道は、要素に還元され た事物の知識を線形的に組み上げて見い出し得るものではあり得ないが、少なくとも 生態系に害禍をもたらすことがない人間介在の物質循環と資源・エネルギーの消費節 減の目標が、人工物の効用の減退と人間の尊厳の袁失を代償とすることなく着実に実 現されて行くところにのみ、見い出されるのであろう。

人間は、“限られた視点からしか事物を見ることができないために、その英知によっ て達成した科学の全てによっても人間の真実は尽くし得るものではない”としても、 人間の問題を考之尽くすには、人間自身の知の全てを結集して考える以外に可能な方 法はない。原自然の方向への回帰が現実に不可能な現代の人間にとっては、繁栄秩序 を探るために可能なことは、科学を避けて“繊細の精神”に絈るのではなく、自然と 人間との関わりを実証的・合理的に究めることなのではないかと考えるのである。意 志の決定を、確認された資料や知識に基づいて実証的・合理的に行おうとする限り、 知識は、自然・社会・人文の全領域において限りなく必要とされるのであり、莫大な 知識を生み出してきた要素還元主義の科学に対する現実社会の期待は拡大しても決し て減退することはない。そして人類が創出して来た学術・文化の全てを、何らかの方 法で総合する努力によって、人間と自然の総体を統べる秩序を見い出す手掛かりを得 ることができると考えたい。しかし、より望ましい繁栄への道を探るために、科学技 術が生み出した成果の全てを、あるいは人間の知の全てを総合するにしても、また個々 の民族文化を全地球的な秩序に総合するにしても、総合の原理を経済効率至上主義や 特定のイデオロギー的な価值観に求めるわけにはいかないのである。総合は、限定さ れた具体性のある目標に対しては、たとえば東海道新幹線の計画・実現の過程におけ るように、関係者の“討議の繰返し”が各々の専門技術の相互に適合を見い出して高 い段階へ進む手続きとして機能する。難解な問題の議論では、対立意見の相互に存在 する同質項・異質項・未定項とそれぞれの根拠を疑義を残さないように明示すること が、反証を可能にして、相互の適合を見い出す契機となる。反証可能性はより普遍へ 進むための不可欠な条件である。そして生体に見い出されるような内的合目的性を作 業仮説的な発見原理として、“個”に相互の適合、あるいはそれを含む“集合”との適 合を探る行き方が、秩序の総合に向けて可能なのではないだろうか。個は、要素技術 でも個人でも、集団や民族でも、相互の “交渉”で変容し適合する可能性をもってお ク、そのために他の個や集合の全体について情報を共有することが不可欠である。

大量の物質を浪費する繁栄が、有限な自然の中で永続しないことは明らかであるが、 一方で人類にとって生存に必要な物質的基礎を確保することは、悲惨な紛争が発生す る事態を避けるために不可欠である。将来に起こり得る世界的状況を適確に予測する 
ことは非常に困難な問題であるが、コンピュータを用いて種々の作業仮説の下に行わ れるシミュレーションは、その検討を行うための資料を提供する。情報科学とコン ピュータ科学は、分科して発達してきた個々の科学技術に対して、たとえば新素材の 創出や地震・津波の挙動解析などのように、その発達を援け、また領域ごとに発達し てきた科学に相互対話を容易にする道を開くことによって、総合化が進む契機となる ことが期待される。一方で今日は、多様な情報があらゆる領域で生み出され続けてお ク、人間の精神に深い影響を与えている。情報環境の過度の拡大は、情報が生まれた 現実とは異質の環境で “座ったまま”その情報を受けとる状況を日常的につくり出し、 今日の知識偏重の教育風潮に重なりあって、自らの“体と五感”による実体験に裏付 けられた知識を獲得しようとする意識を希薄にする効果を生むのではないか。そして 人々は、自分の摇るがない価値観を構築しようなどと悩むよりも、自分を取り巻く自 然や社会の諸条件の直に見える範囲で、情報を選別・処理して利用するという遣り方 で最適解を探ろうとしているように見える。これは、現代的な情報的知が人間的知に とって何を意味するものかという疑問を提示してくる。情報と人間の関わりの根源的 な解明は、情報科学の今日的な基本課題である。

以上は、ことの意を十分には尽していないが、科学技術は“学術と産業”に跨るい ろいろの局面で自然・社会・人文の全体に関わる問題を提起しており、人類は、その 困難を打開して持続的な繁栄秩序を探るために、知の総合と民族文化の総体を視点に おいた判断とが求められていることを述べた。そして要素還元主義の科学技術と情報 科学が、相補的に働いて、総合的な秩序の創成に寄与するとすれば、それは人間と自 然の共生と民族文化の繁栄を内包する世界秩序への意欲によってはじめて可能になる と考えたいのである。

\section{お原面り}

論壇は日本学術会議会員（元会員も含む）や研究連絡委員会委員（元委員も含 む）が、日本学術会議の活動や時事的な事項についての個人的な見解を述べる場 です。もちろん、このコーナーで取り上げた見解に関する意見も歓迎します。

この欄に、意見を述べることを希望される会員等は、編集委員（巻末参照）を 通じてお申し出ください。編集委員が、掲載の時期及び内容の調整にあたります。 掲載字数は、2,000～3,200字です。(原稿はパソコン、ワープロでの作成をお願い いたします。) 